\title{
温暖積雪域における降雪・積雪・融雪水の 酸性度と主要イオン濃度の変動特性 \\ CHARACTERISTICS OF ACIDITY AND MAJOR ION CONCENTRATION OF SNOWFALL, SNOWPACK AND SNOWMELT WATER IN THE TEMPERATE SNOW AREA
}

\author{
朝岡良浩 1 - 竹内由香里 2 \\ Yoshihiro ASAOKA and Yukari TAKEUCHI \\ 1正会員 博（工） 東北大学大学院工学研究科（980-8579 仙台市青葉区荒巻字青葉6-6-06） \\ 2 非会員 博 (地球環境科学) 森林総合研究所 十日町試験地（T948-0013 新潟県十日町市辰乙614）
}

\begin{abstract}
This paper describes the acidity and main ion concentration of snowfall, snowpack and snowmelt water in the temperate snow area. In order to understand the variation of snow water quality and its relationship among snow, snowpack and snowmelt, snow monitoring and chemical measurement were conducted from December 2008 to March 2009 at Tohkamachi experiment site.

As a result, the both of snowfall and snowmelt were high acidity and their average were around 4.6 and 5.0, individually. However, high frequencies of rainfall and snowmelt occurrence during winter decrease the high acidity of snowpack and snowmelt water since they prevent the chemical matter from depositing in the snowpack layer. Moreover, it is suspected that the soil component from Eurasia continent contained in the snow particle also decrease the high acidity of snowfall and snowpack.
\end{abstract}

Key Words : acid snow, temperate snow area, snowmelt, ion concentration, continental origin soil

\section{1. はじめに}

降水に人為起源の硫黄酸化物や窒素酸化物が取り込ま れると酸性化する. 降雪の場合, 地表面に堆積するとこ れらの化学物質が積雪層内に貯留され，融雪期に集中的 に流出するため融雪水のpHが一時的に低下する ような現象はいわゆるアシッドショックと呼ばれ, カナ ダ東部やスカンジナビアでは湖沼のpHが融雪期に急激に 低下する事例が報告されている213). 日本においても札 幌や中部山岳域のような寒冷積雪域において降雪・積雪 の酸性度に関する調査が行われ，降雪・積雪のpHが低く 酸性化寄与物質濃度が高いことも報告されている4)5)6)7)。 渓流水やダム湖の調査も行われ，一時的ではあるものの $\mathrm{pH}$ の低下も観測されている(1)91. しかしながら, 前述の カナダ東部やスカンジナビアと比較すると, 積雪底面か ら流出する融雪水のpHの值は同程度であるものの，土壌 の酸化緩衝機能が高いために地中の流出過程で中和され ることから渓流水のpHがそれほど低下することはない9 一方で，北陸から東北地方の日本海側は世界でも有数の 豪雪地帯であり，冬期でも降雨や融雪が生じる温暖積雪
域に分類される. シベリアや北欧など世界の豪雪地帯と 比較すると冬期でも平均気温が高く, 積雪が堆積する期 間の融雪特性も異なる. 寒冷積雪域と同様に降雪・積雪 や渓流水の酸性度に関する調査が行われ，寒冷な多雪年 には渓流水はpHが一時的に低下するが，温暖な少雪年 には渓流水のpHの低下が緩和されることが報告されて (る9)1011)。しかしながら，温暖積雪域の積雪層から流 出する融雪水の酸性度と化学物質を調査した研究例は少 ない．寒冷積雪域と異なり積雪期間中に降雨や表面融雪 が発生する頻度も高く日変動も大きい. そこで，本研究 では人為起源と海塩起源双方の影響があると考えられる 新潟県十日町市において, 降雪・積雪・融雪のサンプリ ングを行い，それらの酸性度と主要イオン濃度を計測す ることにより時間変動について把握するとともに，降雨 や表面融雪が積雪層から流出する融雪水の水質に及ぼす 影響について評価する.

\section{2. 観測概要}

\section{（1）積雪試料の採取および分析の概要}



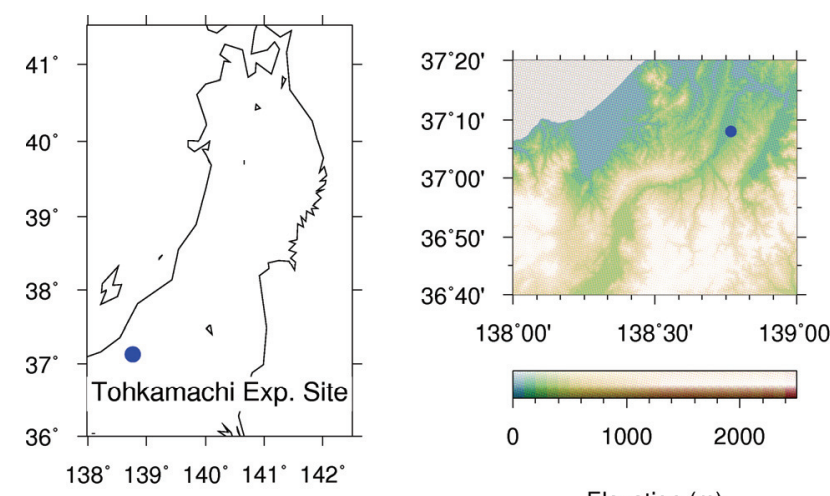

Elevation (m)

図-1＼cjkstart観測サイトの概要

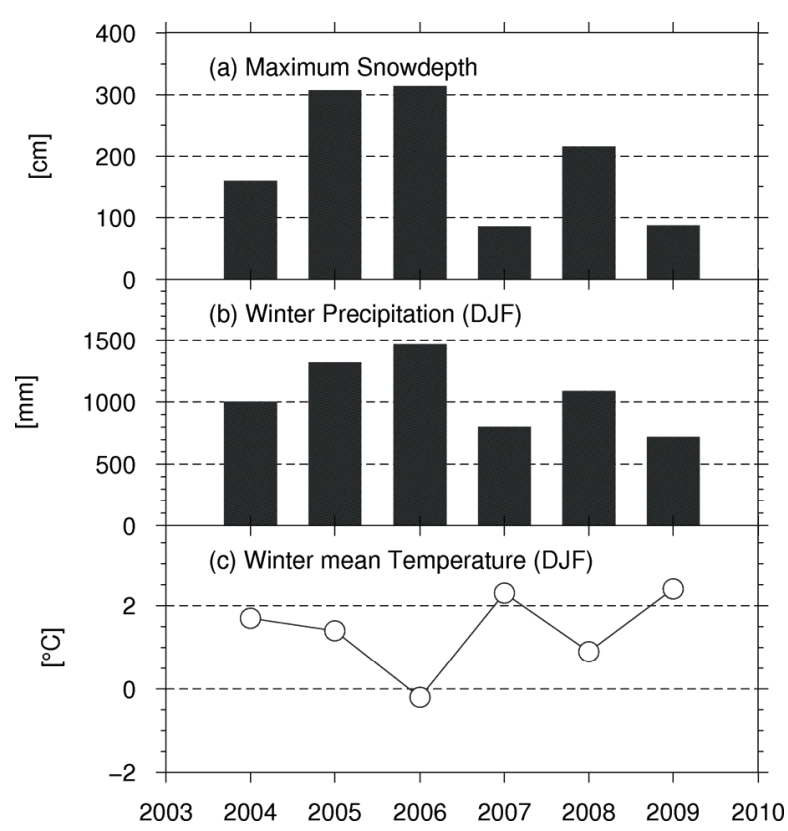

図-2 最大積雪深，冬季降水量，冬季平均気温の年変動 冬季 (DJF) は12月～2月を示す.

本研究では降雪・積雪・融雪水をサンプリングし，酸 性度 $(\mathrm{pH})$, 電気伝導率（EC）, 主要イオン濃度を分 析した. 降雪はプラスチック板を雪面に設置し，堆積し た降雪をほぼ毎日9時頃にサンプリングした．積雪のサ ンプリングは後述する積雪断面観測と併せて行った. ア クリルサンプラーを用いて積雪全層を 5 10cmの層毎に サンプリングした．サンプリングの間隔は断面観測と同 じくほぼ10日に1回である. 融雪水はライシメータから 排出される融雪水をほぼ毎日17時頃に採水した. また, 2月16日と25日には時間変動を把握するため2時間おきに 融雪水のサンプリングを実施した．試料は常温で融解さ せ，メンブランフィルターを用いて前処理を行った.

$\mathrm{pH}, \mathrm{EC}$ はガラス電極法の $\mathrm{pH}$ メータ（東亜DKK，HM30R），電気伝導率計（東亜DKK, CM-30R）を用いて それぞれ測定した. 主要イオン濃度はイオンクロマトグ ラフ（DIONEX社製，ICS-1500）を使用して, $\mathrm{SO}_{4}^{2-}$, $\mathrm{NO}_{3}^{-}, \mathrm{Cl}^{-}, \mathrm{Na}^{+}, \mathrm{NH}_{4}^{+}, \mathrm{Ca}^{2+}, \mathrm{Mg}^{2+}$ の濃度を分析した.

\section{（2）観測サイトの概要}

降雪・積雪・融雪水のサンプリング，断面観測は新潟 県十日町市にある森林総合研究所十日町試験地（北緯 $37^{\circ} 08^{\prime}$ ，東経 $138^{\circ} 46^{\prime}$ ，標高 $200 \mathrm{~m}$ ，図-1）の観測露場 で行った。 ここでは, 気温, 湿度, 降水量, 風速, 日降 雪深, 積雪深, 積雪重量, 地中温度, 正味放射量, ライ シメータによる積雪底面からの流出量がモニタリングさ れている ${ }^{12)}$. 積雪の断面観測はほぼ10日毎に実施され， 2009年冬期の実施日は1月5，14，26日，2月5，16，25日， 3月 5 日の計7回である. 観測項目は積雪深と積雪水量, 各層の雪温，層構造，雪質，密度，含水率，粒径である 13).

過去6年間における最大積雪深，冬期降雪量（12～2 月）, 冬期平均気温の年変動を図-2に示す。なお，本研 究は12月1日から翌年の11月30日を水文年とし，例えば 2008年12月 1 日から 2009 年の 11 月 30 日までを便宜的に 2009年とする. 6 年間の最大積雪深の平均值は $193 \mathrm{~cm}$ と 豪雪域であるが，最大は2006年の $314 \mathrm{~cm} ，$ 最小は2007年 の $84 \mathrm{~cm}$ 年変動も大きいことが特徵である．6年間の冬 期平均気温は $1.4^{\circ} \mathrm{C}$ であり世界の豪雪地帯として比較し ても温暖な気候である。十日町試験地では，最大積雪 深・冬季降水量が多い年には冬期平均気温が低く, 最大 積雪深・降水量が少ない年には冬期平均気温が高くなる 傾向が報告されており ${ }^{14)}$, 過去6年の結果からも同様の 傾向が確認できる．サンプリングを実施した2009年冬期 は最大積雪深 $86 \mathrm{~cm}$, 冬期平均気温 $2.4^{\circ} \mathrm{C}$ であり, 過去 93 年間の最大積雪深の最低值 $81 \mathrm{~cm}$ を記録した 2007 年と同 程度であった。

\section{3. 結果および考察}

\section{（1）降雪}

図-3に2009年冬期の降水中の $\mathrm{pH} ， \mathrm{EC}$ おび $\mathrm{Cl}^{-} ， \mathrm{NO}_{3}^{-}$， $\mathrm{SO}_{4}^{2-}, \mathrm{Ca}^{2+}$ の各種イオン濃度を示す. $\mathrm{pH}$ の平均值は4.6 （標準偏差 $0.5 ）$, 最小值は 3.9 となり, 多くの試料で酸 性降水の基準となる5.6を下回ることが確認された。測 定した陰イオンの中ではCl-の濃度が最も高く ECと高い 相関を示す. $\mathrm{Cl}^{-}$は $\mathrm{Na}^{+}$と相関が高く $\left(\mathrm{R}^{2}=0.99\right)$, 日本海 側に位置する十日町の降雪の大部分が日本海を起源とし ていると考えられる9. $\mathrm{SO}_{4}^{2-}$ の増減と $\mathrm{pH}$ 増減は良く 対応しており, $\mathrm{SO}_{4}^{2-}$ が $\mathrm{pH}$ の低下に最も寄与していると ものと考えられる. 冬季の全体的な傾向として $\mathrm{Cl}^{-}$と $\mathrm{SO}_{4}^{2-}$-の濃度が高くなるとECが高くなり $\mathrm{pH}$ が低下寸る傾 向が確認できる. しかしながら，2月21日の降雪に関し ては冬季全体の傾向と異なり, $\mathrm{EC} と \mathrm{pH}$ 両方が増加し ている. 通常の傾向と異なる点として, $\mathrm{Ca}^{2+}$ の濃度が高 い值を示している. $\mathrm{Ca}^{2+}$ の冬季平均值が $26.8 \mu \mathrm{eq} / 1$ に対し て2月21日の降雪の $\mathrm{Ca}^{2+}$ の濃度は $298.2 \mu \mathrm{eq} / 1$, 非海塩由来 のnssCa ${ }^{2+}$ は2 $242.5 \mu \mathrm{eq} / 1$ と $81 \%$ を占める. 同様に $\mathrm{SO}_{4}^{2-}$ の冬 


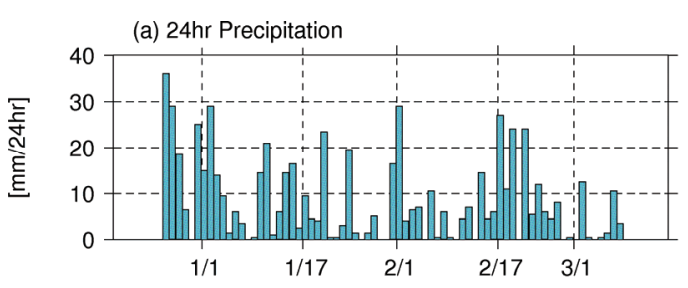

(b) $\mathrm{pH}(\bullet)$ and $\mathrm{EC}(\mathrm{\circ})$

퐁

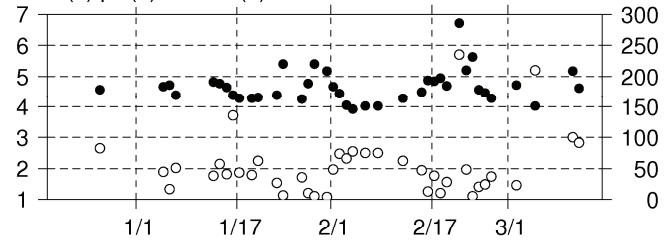

(c) $\mathrm{Cl}^{-}$
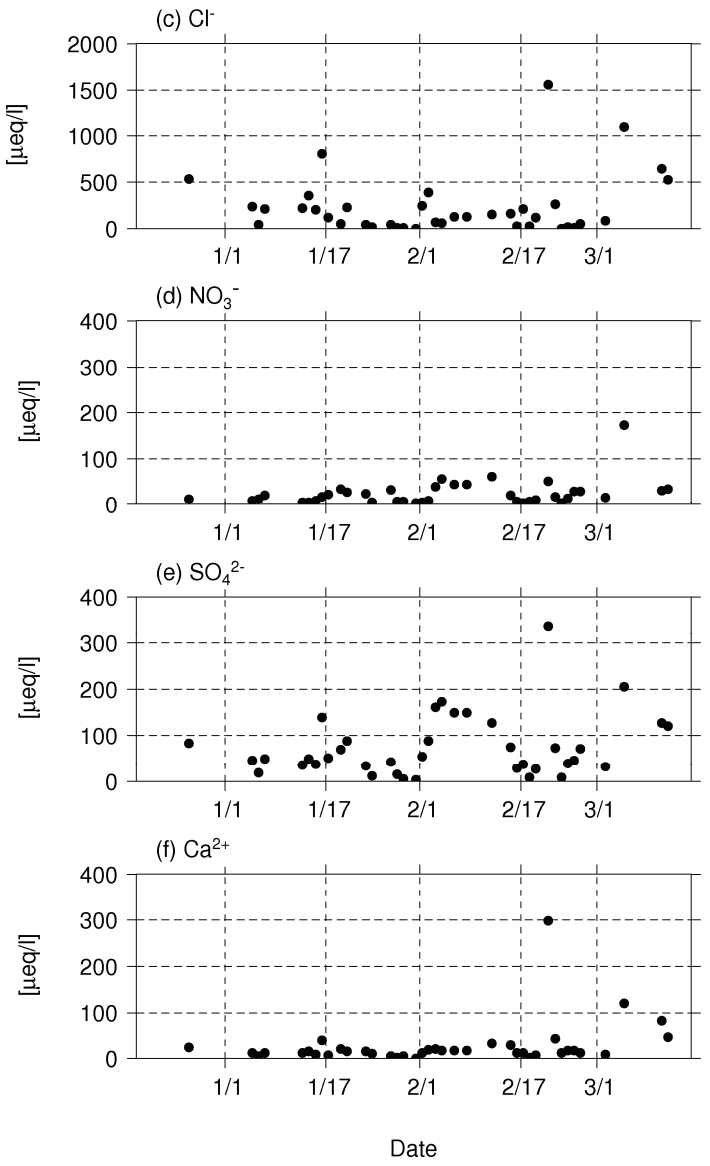

図-3＼cjkstart降水量，pH，EC，各種イオン濃度の観測結果

季平均值が $74.5 \mu \mathrm{eq} / 1$ に対して 2 月 21 日の降雪の $\mathrm{SO}_{4}{ }^{2-}$ は $337.6 \mu \mathrm{eq} / 1$, 非海塩由来のnss $\mathrm{SO}_{4}{ }^{2-}$ - $185.5 \mu \mathrm{eq} / 1$ と55\%を 占める. $\mathrm{Ca}^{2+}$ は主に地表面から巻き上げられた土㙵起源 物質に多く含まれることから ${ }^{1511617)}$ ，大気中の雪雲が黄 砂を取り込み，黄砂を含む降雪があったと推察される.

実際に十日町試験地の降水量と積雪水量の観測值から黄 砂を含む降雪の出現時刻が特定されている ${ }^{18)}$. 黄砂の主 成分である炭酸カルシウムは酸性緩衝作用を持つ性質が ある ${ }^{19)}$. 黄砂の炭酸カルシウムによって, 高い $\mathrm{SO}_{4}{ }^{2-}$ の濃 度にも関わらず $\mathrm{pH}$ 湆加したものと考えられる2021). (a) Snow Water Equivalent

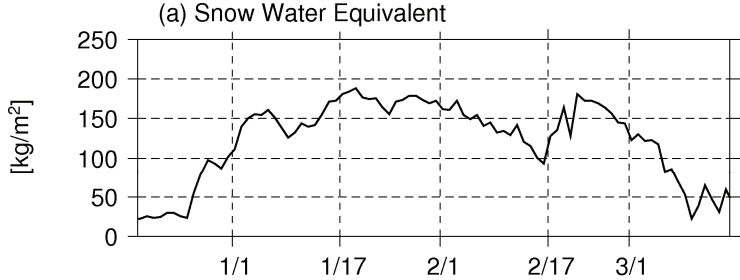

(b) $\mathrm{Cl}^{-}$

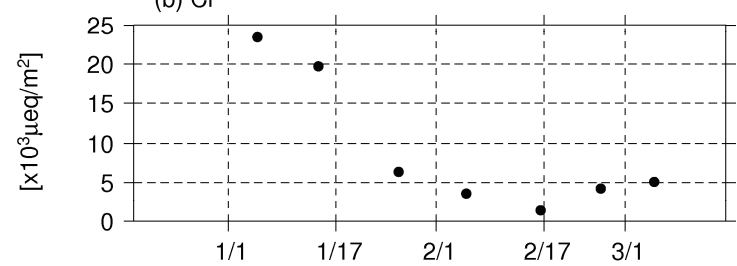

(c) $\mathrm{NO}_{3}^{-}$

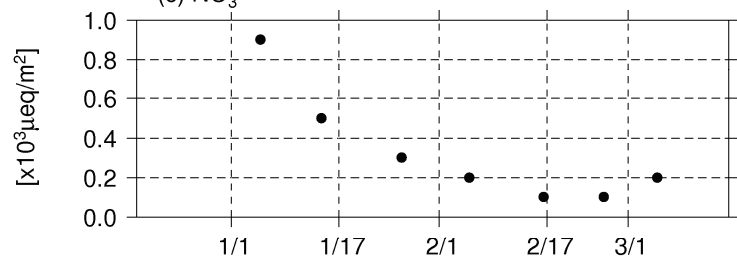

(d) $\mathrm{SO}_{4}{ }^{2-}$

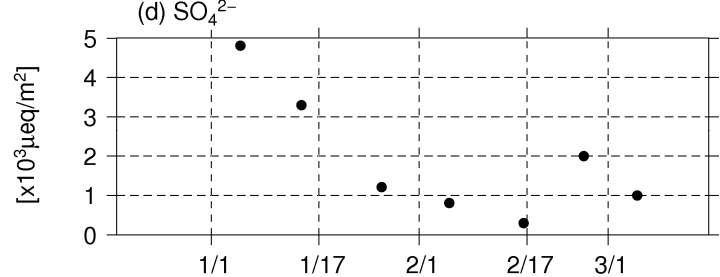

(e) $\mathrm{Ca}^{2+}$

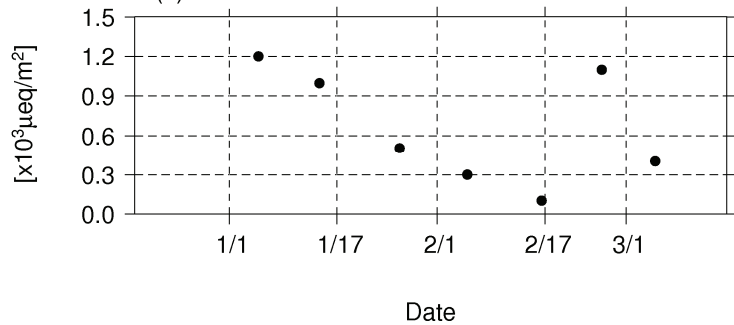

図-4 積雪水量, 積雪層のpH，EC，各種イオンの貯留量

\section{（2）積雪}

図-4に2009年冬期の積雪重量の変化，積雪断面観測で サンプリングした積雪層の分析結果から算出された $\mathrm{Cl}^{-}$, $\mathrm{NO}_{3}{ }^{-}, \mathrm{SO}_{4}{ }^{2-}, \mathrm{Ca}^{2+}$ の貯留量を示す．全ての陰イオンの貯 留量は1月 5 日に最大でその後は減少していることが確認 できる. 図-5に時間降水量を降雨と降雪に判別した降水 量データと時間単位の流量変化を示寸，降雨と降雪の降 水形態判別は，下記に示寸気温 $T$ と湿度を用いて降雨と 降雪の割合を算出する経験式 22 を使用し, 本研究では降 雨割合 $s\left(T_{\mathrm{w}}\right)$ が $50 \%$ 以上の場合を降雨，降雨割合が $50 \%$ 未 満であれば降雪と仮定した.

$$
\begin{array}{cc}
s\left(T_{w}\right)=1-0.5 \exp \left(-2.2\left(1.1-T_{w}\right)^{1.3}\right) & \left(T_{w}<1.1\right) \\
s\left(T_{w}\right)=0.5 \exp \left(-2.2\left(T_{w}-1.1\right)^{1.3}\right) & \left(T_{w} \geq 1.1\right)
\end{array}
$$


(a) Snowfall( $\square$ ) and Rainfall(

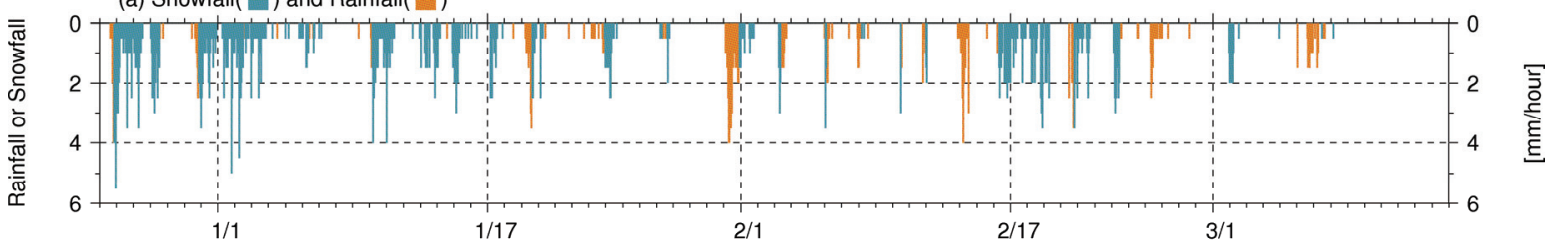

(b) Discharge from lysimeter

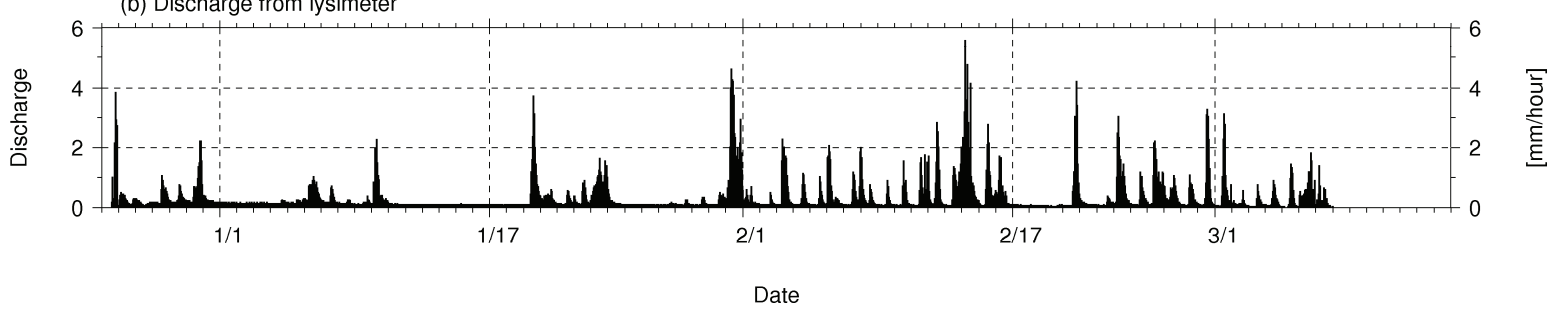

図-5 降水量およびライシメータ流量の変化ライシメータ流量の変化

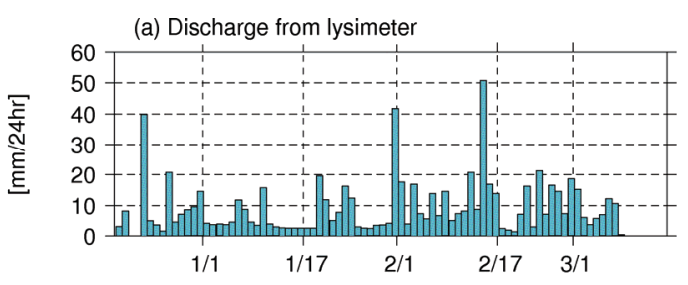

(b) $\mathrm{pH}(\bullet)$ and $\mathrm{EC}(\mathrm{o})$

I

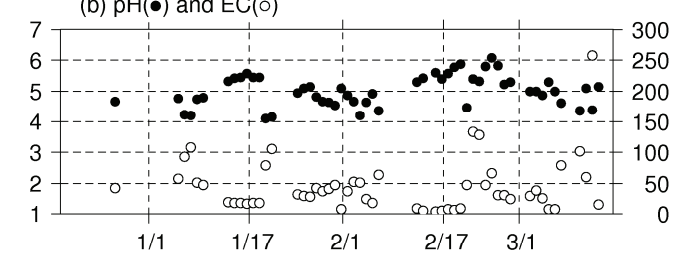

(c) $\mathrm{Cl}^{-}$

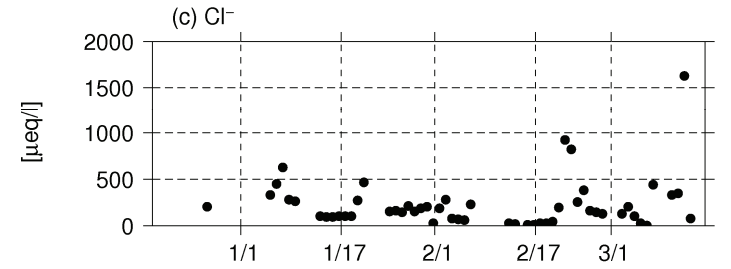

(d) $\mathrm{NO}_{3}^{-}$

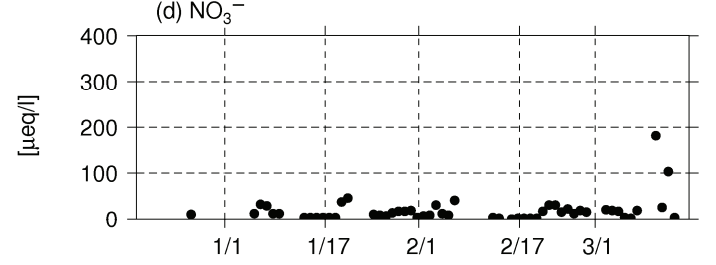

(e) $\mathrm{SO}_{4}^{2-}$
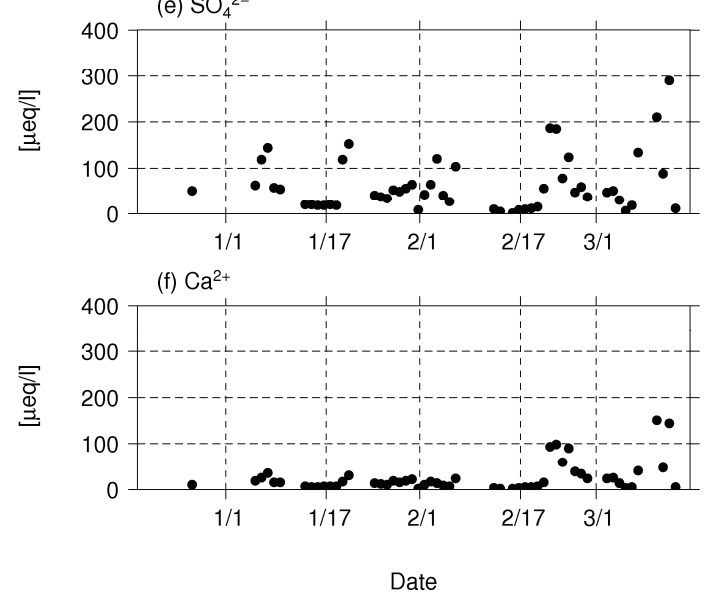

図-6 ライシメータ流量とそのpH，EC，各種イオン濃度
ここで， $T_{\mathrm{w}}$ は湿球温度方程式を $1.1^{\circ} \mathrm{C}$ 付近で展開した近 似式(2)から算定する。

$$
T_{w}=0.584 T+0.875 e-5.32
$$

豆ここで, $e$ は水蒸気圧であり $(\mathrm{hPa})$ であり, Tetens式 ${ }^{23)}$ から 求められる飽和水蒸気圧と観測された湿度から算出する. この図より1月19日，1月31日，2月14日には降雨とその 浸透に伴う積雪底面からの明瞭な流出が確認できる。 た1月31日から2月14日の間にも小規模な降雨による積雪 底面からの流出が確認できる．化学物質を含んだ溶液は 純水よりも水点が低く融点が高くなるため, 積雪層内で 氷粒子が融解・凍結を繰り返し, 化学物質が水粒子の表 面に析出する. 降雨が積雪層内に浸透・透水することに より析出した化学物質を積雪底面から流出させることか ら時間経過に伴い各種イオン濃度の貯留量が減少寸るも のと考えられる.ただし，2月25日の観測で $\mathrm{SO}_{4}^{2-}$ と $\mathrm{Ca}^{2+}$ の総量が増加しているが，これは上述した 2 月 21 日の黄 砂を含んだ降雪の影響に対応したものであると考えられ る.

\section{（3）融雪}

図-6に2009年冬期のライシメータ流量, 積雪底面から 流出する融雪水の $\mathrm{Cl}^{-}, \mathrm{NO}_{3}^{-}, \mathrm{SO}_{4}^{2-}, \mathrm{Ca}^{2+}$ の濃度を示寸. $\mathrm{pH}$ 平均值は5.0（標準偏差0.5）, 最小值は4.1となり, 降雪よりもやや高い值を示寸ものの，多くの試料で酸性 降水の基淮值5.6を下回ることが確認された．特に表面 融雪や降雨が発生せずに底面融雪のみが発生する期間が 7日程度継続（例えば，12月31日〜1月5日，1月12日〜 18 日，1月24日〜2月2日）した後に，降雨や表面融雪が発 生し，積雪層内を浸透することにより積雪底面からの流 量が増加する時（1月6日，1月19日，2月3日）にECの増 加と $\mathrm{pH}$ の低下（4.1前後）が確認できる．また，降雪同 様に融雪水の $\mathrm{pH}$ と $\mathrm{EC} は \mathrm{Cl} ， \mathrm{SO}_{4}{ }^{2-}$ の増減と対応している. 
(a) Snowfall( $\square$ ) and Rainfall(

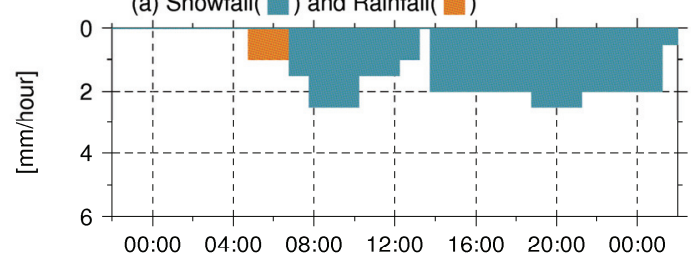

(b) $\mathrm{pH}(\bullet)$ and $\mathrm{EC}(\mathrm{\circ})$

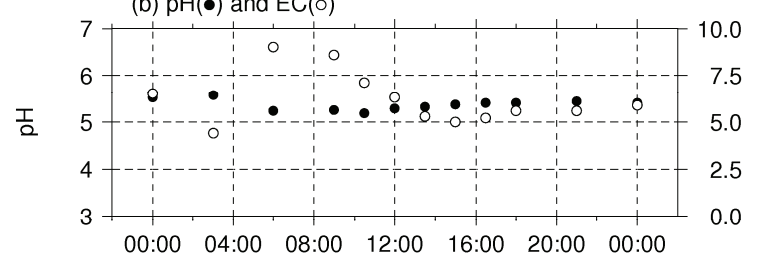

(c) $\mathrm{SO}_{4}{ }^{2-}$

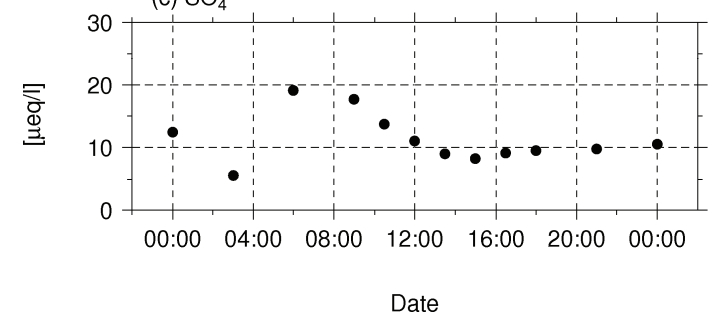

図-7 降水量, 融雪水のpH， $\mathrm{EC}, \mathrm{SO}_{4}^{2-}$-濃度の変化 (2009年2月16日)

これらの要因として, 低流量時すなわち底面融雪のみ発 生する期間は積雪底面の水粒子に析出した化学物質が既 に流出してしいる状態にあり, 降雪から供給される化学 物質は積雪層内に貯留される，積雪層上部から積雪底面 に供給される化学物質がないため, ECが低下し $\mathrm{pH}$ ガ増 加する. その後, 降雨や融雪により積雪層内に貯留され た化学物質がまとめて流出するために $\mathrm{pH}$ 低下寸ると いう機構が考えられる．2009年2月16日と2009年2月25日 の降水量, 融雪量のpHおよびEC, 融雪量の $\mathrm{Ca}^{2+}$ の濃度 の変動を図-7, 図-8にそれぞれ示す。2009年 2 月16日の 5 時に発生した降雨に対応して $\mathrm{SO}_{4}{ }^{2-}$ の増加, それに伴な いECが増加しpHが低下寸るが，その後は降水形態が降 雪に変化することで $\mathrm{SO}_{4}{ }^{2-}, \mathrm{EC}, \mathrm{pH}$ は元の状態に戻るこ とが確認できる.これは，降雨の浸透により降雨に含ま れる硫酸イオンと積雪層の積雪粒子に析出した硫酸イオ ンが流出するが，降雨が降雪に変化するとともに底面か らの流出が底面融雪のみとなり, 降雪から供給される硫 酸イオンは積雪層内に貯留されているものと推察される。 2009年2月 25 日の事例では, 降雨の減少とともに $\mathrm{Ca}^{2+}$ の 濃度が低下し，それに対応してpHとECの両者も低下寸 ることが確認できる。これは2月21日の降雪によって積 雪層内に貯留された土㙵起源物質が融雪と降雨の浸透に より融雪水の酸性度を緩和しているが，降雨の減少とと もに浸透量が減少し, 融雪水の緩和機能が減衰すると推 察される.

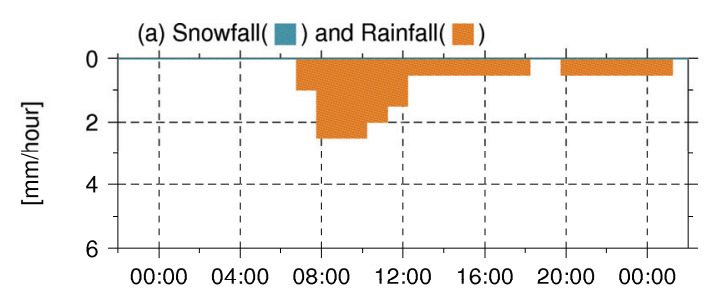

(b) $\mathrm{pH}(\bullet)$ and $\mathrm{EC}(\mathrm{\circ})$

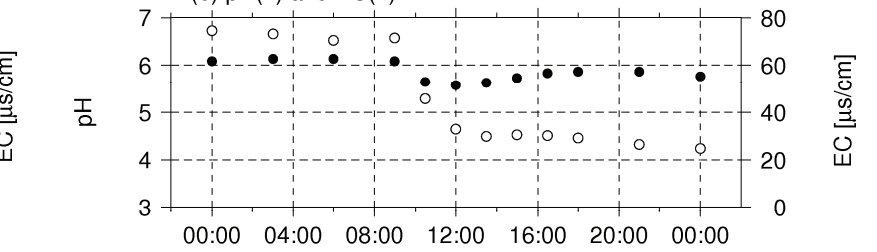

(c) $\mathrm{Ca}^{2+}$

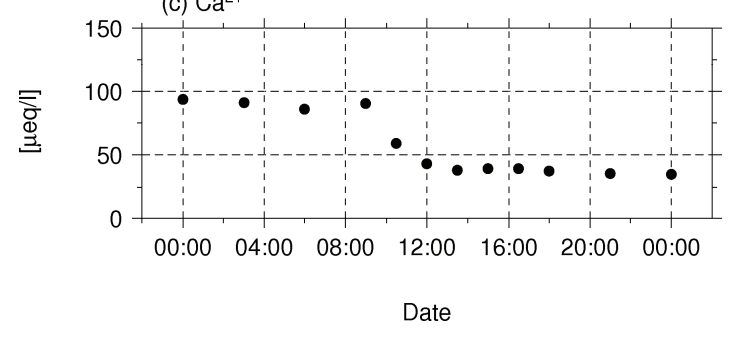

図-8 降水量, 融雪水のpH，EC，Ca2+濃度の変化 (2009年2月25日)

\section{4. おわりに}

本研究では，温暖積雪域である新潟県十日町市におい て2009年冬期の降雪・積雪・融雪水のサンプリングを行 い, $\mathrm{pH}, \mathrm{EC}$, 主要イオン濃度を測定した。 日本では主 に寒冷積雪域を対象として降雪・積雪あるいは渓流水の 測定が実施されてきたが，これまでに観測例が少ない温 暖積雪域の降雪・積雪・融雪の一連の過程を示すことが できたものと考えられる. 得られた結果を以下に列挙す る.

・2009年冬季の降雪と融雪水の平均pHがそれぞれ4.6, 5.0であり, 酸性降水の基準であるpH5.6を下回ることが 示された.

・降雨や表面融雪が発生しない期間が7日程度継続した 後に，降雨や表面融雪が底面に浸透するケースで融雪水 のpHが4.1程度に低下寸ることが確認された。しかしな がら, 温暖積雪域では冬季も高頻度で降雨と融雪が発生 することから融雪水のpHが低下寸る頻度は少ない．

・降雪から土㙥起源物質が供給される場合には, 積雪・ 融雪水の酸性度を緩和することが示唆された.

本研究は積雪量の少ない2009年冬期のみの結果である. 寒冷積雪域と異なり温暖積雪域では降雪量の年変動が大 きい. 積雪量が多い場合には積雪表面で発生した融雪が 積雪層内で涷結融解を繰り返し, 酸性寄与物質が貯留す る可能性も考えられる. このため, 積雪量の多い年も積 
雪のモニタリングと化学物質の測定を継続する必要があ る. また，降雪・積雪・融雪の積雪過程と河川流出過程 を検討することにより, 酸性寄与物質に対する流域全体 の緩衝機能を評価する必要がある.

謝辞 : 本研究はJST/JICA地球規模課題対応国際科学技術 協力事業の援助を受けました. 森林総合研究所の村上茂 樹氏，庭野昭二氏，元職員の遠藤八十一氏には積雪のサ ンプリングに協力して頂きました。電力中央研究所の高 橋 章氏, 若松孝志氏には化学分析に対する助言を頂き ました。ここに記して謝意を示します。

\section{参考文献}

1) 鈴木啓助: わが国における雪水化学研究, 雪水, 62 , pp.185-196, 2000.

2) Johannessen, K. and A. Henriksen, Chemistry of snowmelt water : changes in concentration during melting, Water Resources Research, 14, pp.615-619, 1978.

3) Jeffries, D.S., C.M. Cox and P.J. Dillon: Depression of pH in lakes and streams in cetral Ontario during snowmelt, Journal of Fish.. Res. Bd. Canada, 36, pp.640-646, 1979.

4) 石井吉之 : 北海道における降雪および積雪中の化学成分, 水 文・水資源学会誌，第 7 巻 6 号, pp.566-569, 1994.

5) 石川信敬, 成田英器, 石井吉之: 融雪現象にともなう酸性雪 变質機構の研究, 北海道の農業気像, 第48巻, pp.68-78, 1996 ,

6) Takayuki KURAMOTO, Shailendra Kumar SAHA, Motoki TANAKA and Keisuke SUZUKI: Chemical Characteristics of Snowpack due to Differences in Snowfall Tyep in Japan Alps, Bulletin of Glaciological Research, 26, pp.15-21, 2008.

7) 田中基樹，鈴木啓助 : 山岳積雪中の化学成分の空間分布とそ の成因，雪水，第69巻，pp.371-381, 2007.

8) Aga, H., I. Noguchi and K. Sakata: Aquatic chemistry of a reservoir during the thaw season, Water, Air and Soil Pollution, 130, pp.811816,2001

9) 鈴木啓介: 渓流水の酸性化をもたらす融雪水，地球環境，第 9 巻 1 号, pp.49-60, 2004.

10) 鈴木啓介, 遠藤八十一 : 冬季降水中の海塩起源物質濃度と 気象条件，雪水，第56巻 3 号, pp.233-241, 1994.

11) 鈴木啓助 : 温暖な積雪地における渓流水水質変動, 地学雑 誌, 105, pp.1-14, 1996.
12）竹内由香里, 村上茂樹, 庭野昭二 : ライシメーターと積雪 重量計による融雪流出量の比較. 寒地技術論文・報告集, 第23巻, pp.156-160, 2007.

13）竹内由香里, 遠藤八十一, 庭野昭二, 村上茂樹: 十日町に おける冬期の気象および雪質の調查資料(7)（2004/05〜 2008/09年 5 冬期)，森林総合研究所研究調查報告, 第 8 巻, pp.227-277, 2009.

14) Yukari TAKEUCHI, Yasoichi ENDO and Shigeki MURAKAMI.: High correlation between winter precipitation and air temperature in heavy-snowfall areas in Japan, Annals of Glaciology, 49, pp.7-10, 2009.

15) 新井 正 : 地域分析のための熱・水収支水文学, 古今書院, 2004.

16) KEISUKE SUZUKI and MAYUMI SHIROHADA: Seasonal and temporal changes in the fluxes of major ions via wet and dry depositions, observed in Matsumoto, central Japan, Geochemical Journal, 40, pp.609-623, 2006.

17) Daizhou Zhang, Yasunobu Iwasaka, Atsushi Matsuki, Kazunori Ueno and Tatsuya Matsuzaki: Coarse and accumulation mode particles associated with Asian dust in southwestern Japan, Atmospheric Environment, 40, pp.1205-1215, 2006.

18) 竹内由香里, 中井専人, 石坂雅昭, 熊倉俊郎, 朝岡良浩, 青木一郎：2009年に十日町で観測した黄砂を含む降雪につ いて, 雪水北信越, 第30巻, pp.45, 2010.

19）川村和裕, 原 宏: 日本の降水科学に対する黄砂の影響, 大気環境学会誌, 41巻, pp.335-346, 2006.

20) Masataka NISHIKAWA, Quan HAO and Masatoshi MORITA: Preparation and Evaluation of Certified Reference Materials for Asian Mineral Dust, Global Environmental Research, 4, pp.103113, 2000.

21) Sadayo YABUKI, Masao MIKAMI, Yuki NAKAMURA, Shinji KANAYAMA, Fengfu FU, Mingzhe LIU and Hongfei ZHOU: The Characteristics of Atmospheric at Aksu, an Asian Dust-Source Region of North-West China: A Summary of Observations over the Three Years from March 2001 to April 2004, Journal of the Meteorological Society of Japan, 83, pp.45-72, 2005.

22) 山崎 剛: 厳寒地に適用可能な積雪多層熱収支モデル, 雪 水,第 60巻, pp.131-141, 1998 .

23) 近藤純正編著 : 水環境の気象学, 朝倉書店, 1994.

(2010. 9. 30受付) 